\title{
Evaluation of production of xanthan gum utilizing the corn cob liquor as a carbon source in different strains of Xanthomonas campestres
}

\author{
Meirielly Jesus ${ }^{1 *}$, Petherson Araújo', Tamara Silva', Elisiane Reis', Denise Ruzene', Daniel Silva², Francine Padilha \\ From 5th Congress of the Brazilian Biotechnology Society (SBBIOTEC) \\ Florianópolis, Brazil. 10-14 November 2013
}

\section{Background}

The xanthan gum production has been growing significantly. It is estimated an annual increase by about 5 to $10 \%$. The production needs a carbon source in fermentation media and are commonly employed as glucose or sucrose, which accounts for about $50 \%$ of the cost of production. Therefore the use of agro-industrial residues, such as corn cob for the production of xanthan gum becomes suggestive, as such residues are abundant. Waste when processed becomes a rich source of carbon, nutrients and salts. Thus this study aims to use hemicellulose fractions, derived from agro-industrial residues.

\section{Methods}

The cobs were selected, dried at room temperature and submitted to grinding in knives mill to 16 mesh and then alkaline extraction was performed utilizing $0.75 \mathrm{~mol}$ $\mathrm{NaOH}$ for 120 minutes, and then filtered and stored on cooling $\left(-20^{\circ} \mathrm{C}\right)$ until used [1]. The strain was acquired bank Xanthomonas Institute of Technology and Research, where four strains of Xanthomonas campestris (629, S6, 254 and 1078) are stored in YM medium consisting of (gL-1): extract yeast 3.0, malt extract 3.0, peptone 5.0, sucrose 10.0, and agar 20.0, the microorganism being incubated at $28^{\circ} \mathrm{C}$ for 24 hours. The fermentation process was performed in two steps, the inoculum was prepared by adding $1 \mathrm{ml}$ of bacterial suspension 108 in $14 \mathrm{ml}$ of YM medium incubated on an orbital shaker at $150 \mathrm{rpm}$, $28^{\circ} \mathrm{C}$ for 24 hours. During the second stage, the inoculum was added to $86 \mathrm{~mL}$ of fermentation media. The media were evaluated for carbon sources, and the presence of

'Universidade Tiradentes, Aracaju, SE, Brasil

Full list of author information is available at the end of the article salts. The nutritive media were: M1 (liquor corn cob), M2 (liquor corn cob + salts), M3 (sucrose), M4 (sucrose + salts). After inoculation, was incubated at $180 \mathrm{rpm}$ for 96 hours at $28^{\circ} \mathrm{C}$ [2]. For each experimental condition was performed four replicates, which was analyzed productivity and apparent viscosity. Subsequent to the fermentation broth was centrifuged at $4700 \mathrm{xg}$ for 40 minutes to separate cells. The biopolymer is precipitated with alcohol at $92.6 \%(1: 4 \mathrm{v} / \mathrm{v})$ and followed by drying in an oven at $50^{\circ} \mathrm{C}$ for 24 hours. The samples were dialyzed against water for 24 hours, changed every 6 hours, and subsequently lyophilized and evaluated the apparent viscosity. The viscosity was measured from a $3 \%$ aqueous solution at shear rate of $0-300 \mathrm{~s}^{-1}$.

\section{Results}

The results show that the strains analyzed showed similar behavior as the production of the polymer in the four conditions of fermentation, which emphasized the S6 strain, which exhibited the highest performance in its production in all conditions including in the absence of salts, which the sample M1 obtained 11,7038g. $\mathrm{L}^{-1} \cdot \mathrm{h}^{-1}$ and M2 obtained 6,486475 g. $\mathrm{L}^{-1} \cdot \mathrm{h}^{-1}$ biopolymer. It can be concluded that the results achieved demonstrated the feasibility of obtaining gum in media with the hemicellulose fractions, enabling greater feasibility of process within the context of a biorefinery. The apparent viscosity of aqueous solutions has shown that the use of the corn cob liquor has improved the viscosity of the polymer obtained.

\section{Authors' details}

${ }^{1}$ Universidade Tiradentes, Aracaju, SE, Brasil. ${ }^{2}$ Universidade Federal de Sergipe, SE, Brasil. 


\section{References}

1. Ruzene DS, Silva DP, Vicente AA, GonÇalves AR, Teixeira JA: An Alternative Application to the Portuguese Agro-Industrial Residue: Wheat Straw. Appl Biochem Biotechnol 2008, 147:85-96.

2. Reis EC, Almeida M, Cardoso JC, Pereira MA, Oliveira CBZ, Venceslau EM, Druzian Jl, Mariano R, Padilha FF: Biopolymer Synthesized by Strains of Xanthomonas sp Isolate from Brazil Using Biodiesel-Waste. Macromol Symp 2010, 296:347-353.

doi:10.1186/1753-6561-8-S4-P211

Cite this article as: Jesus et al.: Evaluation of production of xanthan

gum utilizing the corn cob liquor as a carbon source in different strains of Xanthomonas campestres. BMC Proceedings 2014 8(Suppl 4):P211.

\section{Submit your next manuscript to BioMed Central} and take full advantage of:

- Convenient online submission

- Thorough peer review

- No space constraints or color figure charges

- Immediate publication on acceptance

- Inclusion in PubMed, CAS, Scopus and Google Scholar

- Research which is freely available for redistribution

Submit your manuscript at www.biomedcentral.com/submit
C Biomed Central 